Ageing and the Care of Older People in Europe 


\section{Ageing and the Care of Older People in Europe}

Richard Hugman

Consultant Editor: Jo Campling

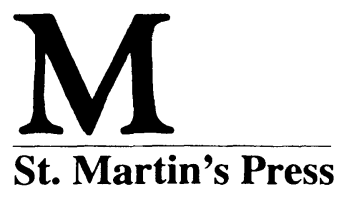


All rights reserved. No reproduction, copy or transmission of this publication may be made without written permission.

No paragraph of this publication may be reproduced, copied or transmitted save with written permission or in accordance with the provisions of the Copyright, Designs and Patents Act 1988, or under the terms of any licence permitting limited copying issued by the Copyright Licensing Agency, 90 Tottenham Court Road, London W1P 9HE.

Any person who does any unauthorised act in relation to this publication may be liable to criminal prosecution and civil claims for damages.

First published in Great Britain 1994 by

THE MACMILLAN PRESS LTD

Houndmills, Basingstoke, Hampshire RG21 2XS

and London

Companies and representatives

throughout the world

A catalogue record for this book is available from the British Library.

ISBN 978-0-333-58749-2

DOI 10.1007/978-1-349-23524-7

First published in the United States of America 1994 by

Scholarly and Reference Division,

ST. MARTIN'S PRESS, INC.,

175 Fifth Avenue,

New York, N.Y. 10010

Library of Congress Cataloging-in-Publication Data

Hugman, Richard, 1954-

Ageing and the care of older people in Europe / Richard Hugman.

p. $\mathrm{cm}$.

Includes bibliographical references and index.

ISBN 978-0-312-12193-8

1. Aged-Care-Europe. 2. Ageing-Social aspects-Europe.

I. Title.

HV1480.H84 1994

$362.6^{\prime} 3^{\prime} 094-\mathrm{dc} 20$

This book is printed on paper suitable for recycling and made from fully managed and sustained forests sources. Logging, and pulping and manufacting processes are expected to conform to the environmental regulations of the country of origin. 
For my parents

who are pleased to say they are

learning to grow older disgracefully 


\section{Contents}

List of Tables viii

Preface and Acknowledgements ix

1 Ageing in European Society 1

2 Polarities and Similarities: An Outline Framework 21

3 History, Economy and Culture 46

4 Respect and Abuse 73

5 Older People and the Welfare Response 97

6 Institution and Community 125

7 Europe: An Ageing Society 152

Bibliography 174

Index 192 


\section{List of Tables}

1.1 Life expectancy at birth, EC countries, 1990

3.1 Proportions of total populations aged over 65 years, EC countries, 1990

3.2 The age at which women and men may obtain retirement pensions, EC countries, 1990

5.1 Degrees of communality in residence and level of care, by service type

5.2 Two spectra of welfare provision compared

6.1 Approximate percentage of people aged over 65 years using institutional or home-care services, late 1980s 


\section{Preface and Acknowledgements}

As we approach the end of the twentieth century one of the most noticeable features of advanced industrial society is that of an increase in the numbers of older people, as well as of the proportions of older people within the overall population. This phenomenon has generated both a growing general interest in ageing and old age and the development of gerontology, bringing together a variety of disciplines in an applied field of enquiry. There has been an accompanying increase in the number of research reports and other texts dealing with different aspects of ageing. For the student of old age there is now a wealth of material, especially that published in English. So, why another book about older people?

The main reason for writing this book is that, although much work has now been done with regard to ageing and old age, for the most part it tends to concentrate on specific national contexts. At a time when Europe increasingly (and however falteringly at times) is becoming an integrated society in which economic, political, cultural and social exchange across national boundaries is ever more important, it becomes necessary to find ways of crossing frontiers in respect of all issues. Ageing, the place of older people in our societies and the care provided for those older people who require it raise important questions for all European countries. Gerontological work from North America has tended to dominate discussions and there is still a relative lack of dialogue between European countries on this topic, although this is now being addressed in developments such as the European Community (EC) Observatory on Ageing, Eurolink Age, and work undertaken by both the Council of Europe and the Commission of the European Community.

This book concentrates on comparative perspectives within Europe and considers the implications of the social construction of and responses to old age in the various European countries. Both the diversities and the commonalities between the different parts of Europe provide a rich background against which to further develop the distinctively European contributions to understanding old age and the place of older people in society. One example of this is the theoretical approach based on political economy, 
grounding social gerontology in a structural analysis of the context in which old age is perceived and experienced. Indeed, as I argue in some detail, this approach provides a cogent underpinning to such debates, and, moreover, it is one which derives from the traditions of European social science. For this reason, in the early chapters I focus on more theoretical aspects, of how ageing and old age may be understood socially, before proceeding in the later chapters to examine historical and contemporary evidence about the types of response which have been made to older people in the fields of health and welfare.

In writing this study I have been encouraged by contact with a range of colleagues who share an interest in a European perspective on ageing. In particular, fellow members of the research group on the family care of older 'elderly people' funded by the European Foundation for the Improvement of Living and Working Conditions (co-ordinated by Robert Anderson) have provided much inspiration, most especially my colleagues at the Lancaster University, Janet Finch and Joy Carter, who formed the United Kingdom group on the project. This book, however, is much broader than that specific topic and seeks to develop an understanding of ageing and old age along several dimensions, placing questions of the care provided for older people within a wider context.

The completion of this text has benefited also from the critical scrutiny of Joy Carter, Jennifer Mason, Liz Mestheneos and Judith Triantafillou, each of whom have read and commented on sections of drafts, and Susan Tester who read it all. Undoubtedly it is the better for their advice, and any remaining weaknesses are entirely my own responsibility. Irini Charitou gave invaluable assistance with translation and my own struggling grasp of Greek; John Sawkins also helped with some translation. Finally, I owe thanks to Frances Arnold and Jo Campling for their encouragement and support, without which this book would not even have been started.

RICHARD HUGMAN 